\title{
プロスタグランジンの血管新生制御機構
}

\section{Regulation of Angiogenesis by Prostaglandin $\mathrm{E}_{2}$}

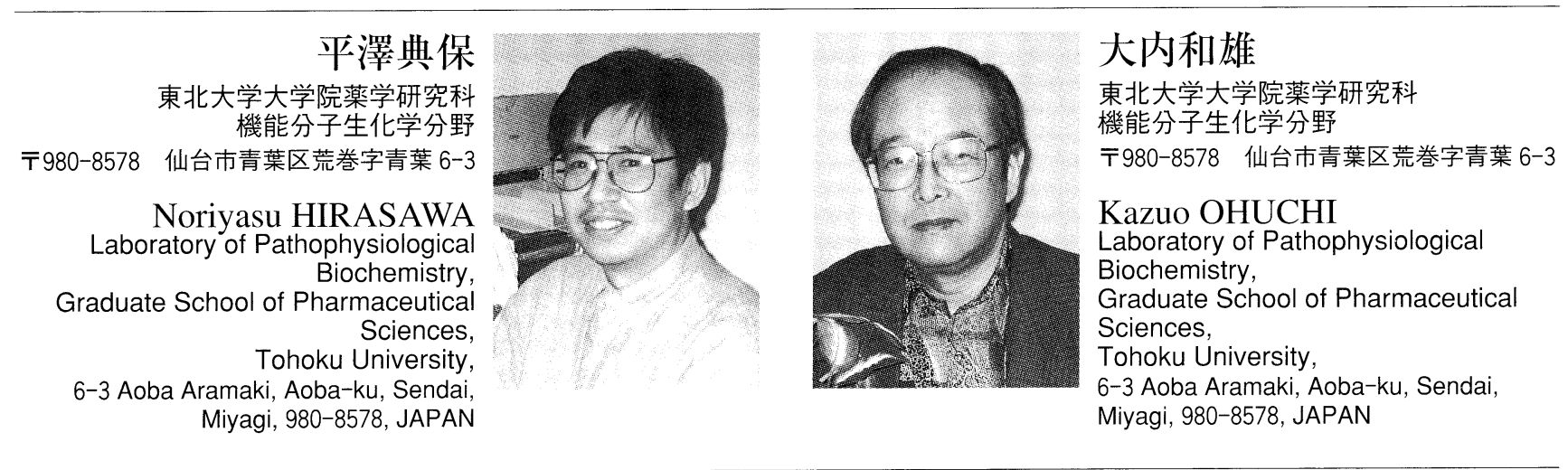

論文要旨：炎症の chemical mediator である prostaglandin $(\mathrm{PG}) \mathrm{E}_{2}$ は，急性炎症反応だけでなく，慢性炎 症にも関与していることが明らかにされてきた。ここでは, cyclooxygenase (COX)-2に由来する $\mathrm{PGE}_{2}$ が肉 芽組織に扔ける血管新生に関与していることについて，筆者らのラットのカラゲニン空気囊型炎症モデルに おける研究成果を中心に最近の知見を紹介する。

ラット背部皮下に作製した空気囊内にカラゲニン溶液を注射すると 3 日後から 6 日後に血管新生を伴う肉 芽組織の増大が見られた。COX-2 選択的阻害薬 NS-398 及び COX-1/COX-2 阻害薬 indomethacin は洷出液 重量, 肉芽重量及び血管新生の増大を抑制し, $\mathrm{COX}-2$ は炎症反応だけでなく, 血管新生にも関与しているこ とが示唆された。NS-398 は渗出液中の血管内皮増殖因子（VEGF）量を低下させたこと， $\mathrm{PGE}_{2}$ は in vitro に おいて，肉芽組織による VEGF 産生を増大させたことから，COX-2 に由来する $\mathrm{PGE}_{2}$ が VEGF の産生を誘 導し，肉芽組織中の血管新生を増大させることが示唆された。さらに $\mathrm{PGE}_{2}$ の VEGF 産生誘導機序について も言及する。

Abstract: The possible participation of prostaglandin $(\mathrm{PG}) \mathrm{E}_{2}$ in angiogenesis in the granulation tissue was analyzed using an air pouch-type carrageenin-induced inflammation model in rats. Injection of carrageenin solution into a pre-formed air pouch on the dorsum induced the increase in the pouch fluid volume, the granulation tissue formation and the angiogenesis in the granulation tissue. The cyclooxygenase (COX)-2 inhibitor NS-398 as well as the COX-1/COX-2 inhibitor indomethacin inhibited all of these parameters, suggesting that COX-2 plays a role in angiogenesis in addition to inflammatory responses. The increase in protein levels of vascular endothelial growth factor (VEGF) in the supernatant fraction of the pouch fluid was inhibited by treatment with NS-398 or indomethacin. To clarify the role of $\mathrm{PGE}_{2}$ in VEGF production, the minced granulation tissue was incubated in the presence of various concentrations of $\mathrm{PGE}_{2}$. It was shown that $\mathrm{PGE}_{2}(0.01-1 \mu \mathrm{M})$ increased $\mathrm{VEGF}$ protein levels in the conditioned medium of the minced granulation tissue and VEGF mRNA levels in the minced granulation tissue in a concentration-dependent manner. These findings suggest that COX-2-derived $\mathrm{PGE}_{2}$ plays a significant role in angiogenesis in the carrageenin-induced granulation tissue through VEGF formation. The mechanism by which $\mathrm{PGE}_{2}$ induces VEGF production is discussed.

Key words: Prostaglandin $\mathrm{E}_{2}$, Cyclooxygenase-2, Angiogenesis, Vascular Endotherial Growth Factor, Inflammatory Granulation Tissue

\section{1 はじめに}

血管新生は，既存の血管から新しい血管が出芽し，毛

連絡者：平澤典保

E-mail : hirasawa@mail.pharm.tohoku.ac.jp
細血管を形成する反応である。この血管新生は，卵巣に おける黄体の形成時など生理的に重要な反応であるだけ でなく, 癌の増殖や損傷治癒, 慢性関節リウマチなどの 増殖型炎症，糖尿病性網膜症など様々な病態形成に深く 関わっている1)。 
生体に炎症刺激が加わると，まず血管透過性立進反応 と好中球浸潤を主体とする急性炎症反応が生じる。続い てマクロファージが浸潤して, 炎症反応が次第に鎮静化 するが，組織傷害などが伴う場合などでは，肉芽形成を 伴う慢性炎症に進展することがある。このような急性炎 症反応から慢性炎症反応へと進展する機構には不明な点 が多い。

Prostaglandin $(\mathrm{PG}) \mathrm{E}_{2}$ は古くから炎症の chemical mediatorの1つとして注目されており，発熱や痛み， 血管透過性立進などを誘発する。近年， $\mathrm{PGE}_{2}$ は急性炎 症だけでなく，血管新生・肉芽組織の形成を伴う慢性炎 症への進展にも関与していることが明らかにされてき た。 $\mathrm{PG}_{\mathrm{s}}$ が血管新生を誘導する作用を示すことはすでに 1980 年代前半から報告されていた。すなわち，1982 年 には $\mathrm{PGE}_{1}$ がウサギの角膜において血管新生を誘発する こと吕，1983 年には $\mathrm{PGE}_{2}$ がニワトリ胚漿尿膜において 血管新生を誘導すること ${ }^{3)}$ が報告され，さらに 1984 年に は indomethacin がウサギ角膜における血管新生を抑制 すること ${ }^{4)}$ が報告された。しかし，慢性炎症における肉 芽組織中で見られる血管新生に内因性の $\mathrm{PG}_{\mathrm{s}}$ が関与して いるかどうか，また $\mathrm{PG}_{\mathrm{s}}$ がどのように血管新生を誘導す るかについては近年まで明らかにされていなかった。血 管新生を誘導する増殖因子として血管内皮増殖因子 (vascular endothelial growth factor ; VEGF) が見いだ され ${ }^{5)}, \mathrm{PG}_{\mathrm{s}}$ が VEGF の産生を誘導することが明らかに されて, $\mathrm{PG}_{\mathrm{s}}$ による血管新生誘導作用機構が分子レベル で議論されるようになった。本稿では, 炎症性肉芽組織 中の血管新生及び VEGF 産生における $\mathrm{PG}_{\mathrm{s}}$ の関与につ いて，ラットの増殖型炎症モデルを用いた筆者らの知 見 ${ }^{6)}$ を心に紹介する。

\section{$2 \mathrm{PG}_{\mathrm{s}}$ の産生機構と受容体}

$\mathrm{PG}_{\mathrm{s}}$ は細胞膜の構成成分であるリン脂質から phospholipase $\mathrm{A}_{2}\left(\mathrm{PLA}_{2}\right)$ により切り出された不飽和脂肪酸 arachidonic acid から産生される。Cyclooxygenase (COX) は arachidonic acidに2 分子の酸素を付加して $\mathrm{PGG}_{2}$ を産生し，続いて $\mathrm{PGH}_{2}$ に還元する 2 段階反応を 触媒する。生成した $\mathrm{PGH}_{2}$ はさらに $\mathrm{PGE}$ 合成酵素 (PGE synthase ; PGES) により $\mathrm{PGE}_{2}$ へ変換される。ま た PGD 合成酵素，PGI 合成酵素及び TX 合成酵素によ りそれぞれ $\mathrm{PGD}_{2}, \mathrm{PGI}_{2}$ 及び $\mathrm{TXA}_{2}$ が合成される。COX には構成的に発現している $\mathrm{COX}-1$ と炎症性サイトカイ ン等の刺激により誘導される COX-2 の 2 つのアイソザ イムが存在する。また PGESにも構成的に細胞質に存在 する cPGES と誘導型で膜に局在する mPGES がある7)。 構成的な COX-1 及び cPGES は主として生理的な $\mathrm{PG}_{\mathrm{s}}$
の産生に，誘導型の COX-2 と mPGES は病理的な $\mathrm{PG}_{\mathrm{s}}$ 産生に関与しており，COX-2 を選択的に阻害する薬物 の中には副作用の少ない抗炎症薬として使用されている ものがある。

$\mathrm{PG}_{\mathrm{s}}$ は受容体を介して作用を発現するが，PGE $\mathrm{PGD}_{2}, \mathrm{PGI}_{2}$ 及び $\mathrm{TXA}_{2}$ の受容体はそれぞれ，EP，DP， IP 及び TP と命名された。さらに EP 受容体には EP 1 から EP 4 までの 4 種類が報告されている ${ }^{8)}$ 。EP 1 は $\mathrm{Ca}^{2+}$ 動員系，EP 2 と EP 4 は adenylate cyclase の活性 化，EP 3 は adenylate cyclase の抑制に共役しており, $\mathrm{PGE}_{2}$ の多様な生理作用が受容体レベルで明らかにされ つつある。

\section{3 カラゲニン誘発空気囊型炎症モデルにおける肉芽組 織の形成と血管新生}

筆者らは炎症性肉芽組織中の血管新生に COX-2 由来 の $\mathrm{PGE}_{2}$ が関与しているかどうか，ラットのカラゲニン 空気囊型炎症モデルを用いて解析した ${ }^{6)}$ 。本実験モデル は，ラットの背部皮下に空気 $8 \mathrm{ml}$ を注射して空気囊を 作製し, 翌日, 空気囊内に起炎剤であるカラゲニン溶液 $(2 \%(\mathrm{w} / \mathrm{v})$ carrageenin $-0.9 \%(\mathrm{w} / \mathrm{v}) \mathrm{NaCl}$ 溶液 $) 4 \mathrm{ml}$ を 注入して炎症反応を誘発するものである。空気囊は腹腔 や関節腔などに相当する体腔を背部皮下に人工的に作製 したものであり，炎症反応により毛細血管から漏出した 血漿成分が貯留する場になる。このモデルは空気囊内に 貯留した渗出液の重量や渗出液中の浸潤白血球数, 並び に各種 chemical mediators について再現性よく定量的に 測定することが可能であり，炎症反応や薬物効果を薬理 学的にも, 生化学的にも解析することができる利点を備 えたモデルである。このモデルは血漿滲出反応が強いだ けでなく，増殖型肉芽組織の形成も顕著である。カラゲ ニン溶液を注入して 3 日後には空気囊内壁に沿った袋状 の肉芽組織を肉眼的に観察することができ，6 日後にか けて肉芽組織の重量が増加する（Table 1）。この間，袋 状の肉芽組織内に貯留する渗出液量は著しく増大し （Table 1)，血管新生に伴う血漿漏出が生じていると考 えられる。そこで，この肉芽形成に伴う血管新生を定量 化及び可視化することを試みた。肉芽組織中の血管量を 測定するために， carmine dyeを用いた。 $37^{\circ} \mathrm{C} に$ 保温し た $5 \%(\mathrm{w} / \mathrm{v})$ carmine dye $-5 \%(\mathrm{w} / \mathrm{v})$ gelatin 含む水溶 液 $3 \mathrm{ml}$ を静脈注射したのち, 肉芽組織を摘出してその 重量を測定後，ホモジナイズして carmine dye を抽出 し，比色定量した。その結果，3〜6日にかけて肉芽組 織の増大に伴い，肉芽組織中の carmine dye 量も増大し た（Table 1）。この増加が血管新生によるものかどうか を明らかにするために，形成された血管網を可視化し 
Table 1 Time Course of Pouch Fluid Accumulation, Total Number of Infiltrated Leukocytes in the Pouch Fluid, Granulation Tissue Weight and the Carmine Dye Content in the Whole Granulation Tissues in the Carrageenin-induced Inflammation.

\begin{tabular}{|c|c|c|c|}
\hline & \multicolumn{3}{|c|}{ Days after Carrageenin Injection } \\
\hline & 1 & 3 & 6 \\
\hline Pouch Fluid (ml) & $6.9 \pm 0.6$ & $7.1 \pm 1.9$ & $29.2 \pm 3.3^{\mathrm{a}}$ \\
\hline $\begin{array}{l}\text { Total number of Leukocytes } \\
\left(\times 10^{7} \text { cells }\right)\end{array}$ & $47.0 \pm 6.3$ & $23.3 \pm 2.5^{\mathrm{a}}$ & $6.3 \pm 0.2^{\mathrm{a}}$ \\
\hline Granulation Tissue (g) & N.D. & $6.9 \pm 0.7$ & $11.1 \pm 1.0^{\mathrm{b}}$ \\
\hline $\begin{array}{l}\text { Carmine Dye Content } \\
\text { (mg/whole granulation tissue) }\end{array}$ & N.D. & $0.45 \pm 0.03$ & $1.03 \pm 0.07^{\mathrm{b}}$ \\
\hline
\end{tabular}

Values are the means \pm S.E.M. from 6 rats. ${ }^{a} \mathrm{P}<0.001$ vs. day $1,{ }^{b} \mathrm{P}<0.001$ vs. day 3. N.D., not determined.

た。血管内皮細胞に特異的に結合するレクチン Griffonia simplifolia agglutinin-Iを用いて 5 日目の肉芽組織中の 血管内皮細胞を染色したところ，Fig. 1Aに示すように 既存の血管から新生血管が発芽している様子が観察され た。また，肉芽組織を固定・脱水処理後，cederwood oil 中に 14 日間浸した後, 顕微鏡下で carmine dye を含 む血管を観察したところ, 肉芽重量が増加する 3 日目か ら6日目にかけて肉芽組織中の毛細血管が著しく増加し た（Fig. 1B）。これらのことから，肉芽形成に伴い，血 管新生が生じていることが示唆された。

\section{$4 \operatorname{cox}$ 阻害薬の抗炎症効果}

カラゲニン溶液を空気囊内に注射して 6 日後の肉芽組 織中の COXをWestern blot 法により検出した結果, COX-1 及び COX-2 ともに検出された (デー夕未掲載)。 また，6日目の渗出液中には $\mathrm{PGE}_{2}$ が検出された（Table 2)。COX-2 選択的阻害薬である NS-398 $(100 \mu \mathrm{g})$ ある いは COX-1/COX-2 非選択的阻害薬である indomethacin $(100 \mu \mathrm{g})$ をカラゲニン溶液注射直後，2 日後及び 4 日後 に空気囊内に注射した結果，6日後の滲出液中の $\mathrm{PGE}_{2}$ レベルは両薬物によって著しく低下した（Table 2）。し たがって, 本モデルの慢性炎症の滲出液中の $\mathrm{PGE}_{2}$ の増 加には COX-2 が大きく関与していることが示唆された。 NS-398（10，30，100 $\mu \mathrm{g} ）$ は滲出液量, 浸潤白血球数及 び肉芽重量を濃度依存的に有意に低下させた（Table 2)。NS-398 $(100 \mu \mathrm{g})$ の抑制作用は indomethacin $(100 \mu \mathrm{g})$ とほぼ同程度であった。また，両薬物とも肉 芽組織中の carmine dye 量を肉芽重量よりもやや強く低 下させた。これらの結果から，COX-2 阻害薬は抗炎症 作用を示すとともに，血管新生を低下させることが示唆 された。

Majima $ら^{9)}$ は塩基性線維芽細胞増殖因子（basic fibrob-
(A)

\section{Day 5}

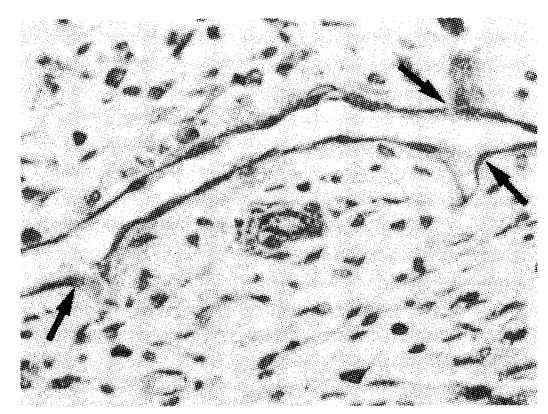

(B)
Day 3

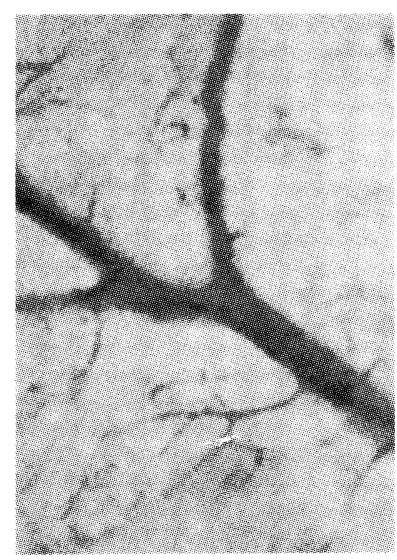

Day 6

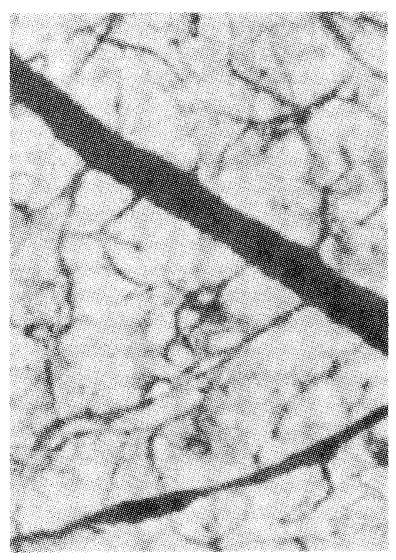

Fig. 1 Small Vascular Network Formation in Carrageenininduced Granulation Tissue. Four milliliters of a $2 \%(\mathrm{w} / \mathrm{v})$ carrageenin solution in saline was injected into the air pouch. (A) The endothelial cells in the granulation tissue 5 days after carrageenin injection were stained with Griffonia simplifolia agglutinin-I ( $400 \times$ magnification). The sprouts of vessels are indicated by arrows. (B) The small vascular network in the granulation tissues 3 days (left) and 6 days (right) after carrageenin injection was visualized as described in the text $(40 \times$ magnification). 
Table 2 Effects of NS-398 and Indomethacin on Pouch Fluid Accumulation, Total Number of Infiltrated Leukocytes in the Pouch Fluid, Granulation Tissue Weight and the Carmine Dye Content in the Whole Granulation Tissues 6 Days after Carrageenin Injection. NS-398 or indomethacin was injected into the pouch 0,2 and 4 days after carrageenin injection.

\begin{tabular}{|c|c|c|c|c|c|}
\hline & \multicolumn{4}{|c|}{ NS-398 ( $\mu \mathrm{g})$} & \multirow{2}{*}{$\frac{\text { Indomethacin }(\mu \mathrm{g})}{100}$} \\
\hline & 0 & 10 & 30 & 100 & \\
\hline Pouch Fluid (ml) & $30.6 \pm 1.2$ & $25.6 \pm 1.0^{\mathrm{a}}$ & $22.4 \pm 2.1^{\mathrm{b}}$ & $20.0 \pm 1.2^{\mathrm{c}}$ & $19.8 \pm 1.3^{\mathrm{c}}$ \\
\hline $\begin{array}{l}\text { Total number of Leukocytes } \\
\left(\times 10^{7} \text { cells }\right)\end{array}$ & $6.3 \pm 1.2$ & $5.5 \pm 1.9^{\mathrm{b}}$ & $4.3 \pm 1.6^{c}$ & $3.1 \pm 1.1^{c}$ & $2.9 \pm 0.7^{\mathrm{c}}$ \\
\hline Granulation Tissue (g) & $9.4 \pm 0.3$ & $8.4 \pm 0.1^{b}$ & $7.8 \pm 0.3^{b}$ & $7.3 \pm 0.2^{\mathrm{c}}$ & $7.5 \pm 0.2^{\mathrm{c}}$ \\
\hline $\begin{array}{l}\text { Carmine Dye Content } \\
\text { (mg/whole granulation tissue) }\end{array}$ & $1.09 \pm 0.03$ & $0.85 \pm 0.02^{c}$ & $0.72 \pm 0.03^{c}$ & $0.62 \pm 0.01^{\mathrm{c}}$ & $0.63 \pm 0.01^{\mathrm{c}}$ \\
\hline $\mathrm{PGE}_{2}$ (ng/pouch) & $42 \pm 8$ & N.D. & N.D. & $3 \pm 0.4^{\mathrm{c}}$ & $3 \pm 0.5$ \\
\hline
\end{tabular}

last growth factor；bFGF）をスポンジにしみ込ませて 皮下に移植するラットのモデルを用いて，増殖因子によ る血管新生機構を解析し，bFGFによりスポンジの周囲 に血管新生を伴う肉芽形成が増加すること，この増大 は NS-398 で抑制されることを示した。さらに Kuwano ら ${ }^{10)}$ は COX-2 欠損マウスでは炎症性のサイトカイン interleukin- $1 \beta$ （IL-1 $1 \beta$ ）による血管新生充進作用が著し く減弱することを報告している。このように，マウス増 殖因子や炎症性サイトカインによる血管新生の誘導にも COX-2 が関与していることが明らかにされている。

\section{VEGF の産生と COX 阻害薬の効果}

カラゲニン空気囊型炎症モデルにおいて，COX-2 阻 害薬の血管新生抑制作用機構を明らかにするために，渗 出液中の VEGF 量をWestern blot 法で解析した6)。そ の結果，カラゲニン溶液注射 3 日後の渗出液中に VEGF が検出され，さらに 6 日後の渗出液中の VEGF 濃度は 3 日後の約 2 倍に増加した ${ }^{6)}$ 。そこで VEGF 産生に対する NS-398 及び indomethacinの効果を検討した。NS-398 及び indomethacin をカラゲニン溶液注射直後，2 日後 及び 4 日後に空気囊内に注射して，6 日後に採取した渗 出液中の VEGF 濃度は NS-398 の濃度（10，30，100 $\mu \mathrm{g} ）$ に依存して低下し，100 $\mu \mathrm{g}$ の NS-398 は $100 \mu \mathrm{g}$ の indomethacin と同程度の抑制作用を示した（Fig. 2)。こ れらの結果から，COX-2 阻害薬はVEGF 産生を低下さ せることにより，肉芽組織中の血管新生を抑制すること が示唆された。さらに，Kamei ら ${ }^{111}$ は，炎症局所での $\mathrm{PGE}_{2}$ の産生，VEGF の産生及び血管新生に mPGES-1 が関与していることを mPGES-1 久損マウスを用いて明 らかにした。すなわち，mPGES-1 を欠損するマウスで は，起炎刺激として cotton thread を移植した場合，野 生型マウスに比べて $\mathrm{PGE}_{2}$ の産生が低下し，さらに VEGF の産生及び血管新生が減弱した ${ }^{11}$ 。これらの結果
から，炎症反応により形成される肉芽組織では COX-2 及び mPGES-1の誘導が生じ，これらの酵素により合成 される $\mathrm{PGE}_{2}$ が VEGF の産生を誘導して，血管新生を促 進すると考えられる。

\section{$6 \mathrm{PGE}_{2}$ による肉芽組織における VEGF 産生}

COX 阻害薬は，Table 2 に示すように白血球浸潤や肉 芽増殖も抑制することから，VEGF 産生細胞の浸潤ある いは増殖を抑制することにより，沴出液中の VEGFレ ベルを低下させた可能性も考えられる。そこで， $\mathrm{PGE}_{2}$

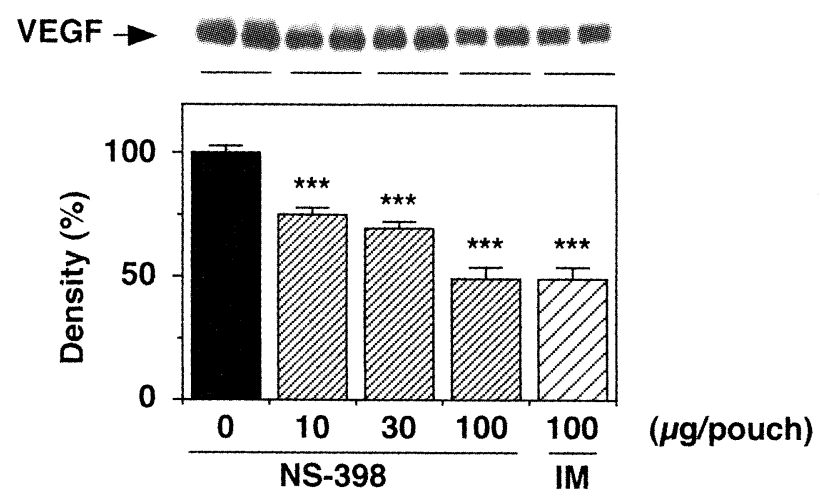

Fig. 2 Effects of NS-398 and Indomethacin on VEGF Protein Levels in the Pouch Fluid. Four milliliters of a $2 \%(\mathrm{w} / \mathrm{v})$ carrageenin solution in saline was injected into the air pouch. NS-398 (10, 30, and $100 \mu \mathrm{g}$ ) or indomethacin (IM, $100 \mu \mathrm{g}$ ) dissolved in $500 \mu \mathrm{l}$ of saline was injected into the pouch 0,2 and 4 days after carrageenin injection. VEGF proteins in the supernatant fractions of the pouch fluids collected 6 days after carrageenin injection were immunoblotted and analyzed densitometrically. The immunoblots of VEGF proteins in the pouch fluid from 2 rats in each group are shown on the top. Values are the means with S.E.M. shown by vertical bars from 6 rats. The mean density in the control group is set to $100 \%$. Statistical significance: ${ }^{* * *} P<0.001$ versus control. 
A)

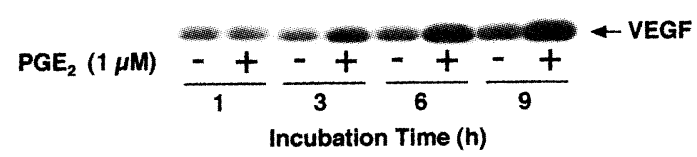

B)

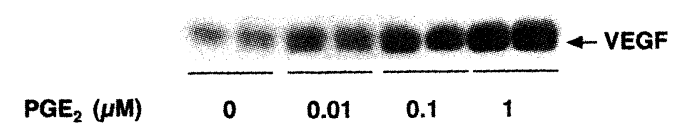

C)

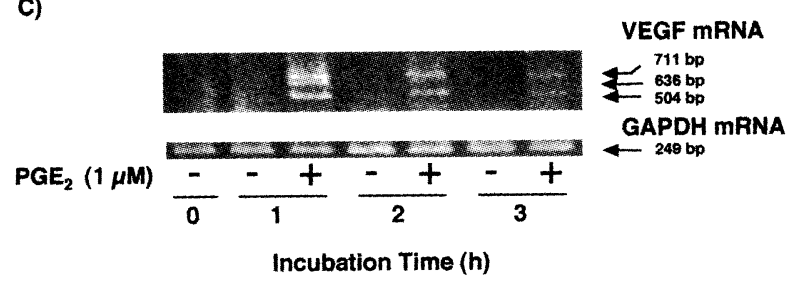

D)

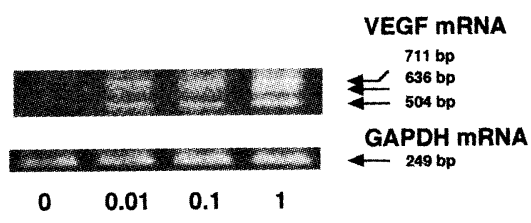

$\mathrm{PGE}_{2}(\mu \mathrm{M})$

Fig. 3 Induction of VEGF Production by $\mathrm{PGE}_{2}$ in the Minced Granulation Tissue. The minced granulation tissue $(0.8 \mathrm{~g})$ was incubated in $4 \mathrm{ml}$ of EMEM containing $10 \%(\mathrm{v} / \mathrm{v})$ calf serum at $37^{\circ} \mathrm{C}$ for $3 \mathrm{~h}$. After three washes, the tissue was further incubated at $37^{\circ} \mathrm{C}$ for the periods indicated in the presence or absence of $\mathrm{PGE}_{2}(1 \mu \mathrm{M})(\mathrm{A}$ and $\mathrm{C})$, or for $6 \mathrm{~h}(\mathrm{~B})$ or $1 \mathrm{~h}(\mathrm{D})$ in the presence of $\mathrm{PGE}_{2}$ at the concentrations indicated. VEGF protein in the conditioned medium of the minced granulation tissue were detected by immunoblotting (A and B). The VEGF mRNA in the minced granulation tissue was detected by RT-PCR (C and D). The rat glyceraldehyde 3-phosphate dehydrogenase (GAPDH) gene (a housekeeping gene) was used as an internal standard gene.

に肉芽組織中の細胞の VEGF 産生を直接誘導する活性 があるかどうか, 肉芽組織の培養系で解析した ${ }^{6)}$ 。内因 性の $\mathrm{PGE}_{2}$ の影響を少なくするためにカラゲニン溶液を 空気囊内に注入した直後及び 2 日後にindomethacin $(100 \mu \mathrm{g})$ を空気囊内に投与し，3 日目の肉芽組織を摘出 した。得られた肉芽組織を $1 \sim 2 \mathrm{~mm}$ 角に mince し, $\mathrm{PGE}_{2}$ 存在下で培養して, VEGF の産生について解析し た。 $\mathrm{PGE}_{2}(1 \mu \mathrm{M})$ で刺激し, 経時的に培養液上清中の VEGF 濃度をWestern blot 法で解析したところ， VEGF 濃度は培養開始 3 時間目ごろから経時的に増大し た（Fig. 3A）。また, VEGF 濃度の上昇は $0.01 \mu \mathrm{M}$ 以上 の濃度の $\mathrm{PGE}_{2}$ で認められた (Fig. 3B)。

$\mathrm{PGE}_{2}$ による VEGF 濃度の上昇は，肉芽組織中の細胞 内に合成・貯留されていた VEGF が $\mathrm{PGE}_{2}$ により細胞外
に放出された可能性が考えられたため, 肉芽組織中の VEGF mRNA レベルを RT-PCR 法で解析した。その結 果, VEGF mRNA レベルは $\mathrm{PGE}_{2}$ を添加して 1 時間後 をピークとして増大し（Fig. 3C), VEGF タンパク量の 増加とほぼ同様の濃度依存性が認められた（Fig. 3D）。 これらの結果から, $\mathrm{PGE}_{2}$ は肉芽組織中の細胞の VEGF 産生を誘導することが示唆された。またVEGFには 3 つのアイソフォームがあり ${ }^{12)}$, RT-PCR で 711，636 及 び $504 \mathrm{bp}$ に検出された PCR 産物は，それぞれ 188 アミ ノ酸，164アミノ酸及び 120 アミノ酸からなるVEGF の アイソフォームに相当する。このように肉芽組織ではこ れら 3 つアイソフォームがいずれも産生されているこ とが明らかになった。

\section{VEGF 産生誘導機構}

VEGF は血管の周囲の線維芽細胞などの実質細胞が低 酸素状態に陥った時に産生され，血管内皮細胞に作用し て血管新生を誘導する。低酸素状態における VEGF 産 生は，転写因子 hypoxia-inducible factor-1 (HIF-1) が関与している ${ }^{13)}$ 。 HIF-1 は HIF-1 $\alpha$ と HIF-1 $\beta$ のへテ ロ 2 量体である ${ }^{14)}$ 。HIF-1 $\beta$ レベルは酸素分圧によって 変化しないが, HIF- $1 \alpha$ は正常酸素分圧下では分解が䒕 進して，そのタンパク質レベルは極めて低く維持されて いる。しかし, 低酸素分圧下になると, HIF-1 $\alpha$ の安定 性が増大して HIF-1 $\alpha$ レベルが上昇し, HIF-1 $\beta$ と 2 量 体を形成して VEGF の転写を増大させる ${ }^{15)}$ 。

$\mathrm{PGE}_{2}$ がどのような分子機序で VEGF の産生を増大さ せるかについては, in vitro 及び in vivoで解析されてお り，低酸素状態におけるVEGF 産生機序とは異なった 機序によることが明らかにされている。 $\mathrm{PGE}_{2}$ は上述の ように，EP 2 及び EP 4 受容体を介して細胞内セカンド メッセンジャーである cyclic adenosine 3', 5'-monophosphate (cAMP) を増加させ, EP 1 を介して細胞内 $\mathrm{Ca}^{2+}$ 濃度の上昇と protein kinase C (PKC) の活性化を誘導 する。Harada ら ${ }^{16)}$ は骨芽細胞株 $\mathrm{RCT}-3$ を用いて, $\mathrm{PGE}_{2}$ によるVEGF 産生は $\mathrm{cAMP}$ 拮抗薬で抑制される ことを示し，また，Ben-Av ら ${ }^{17)}$ は，リウマチ患者の滑 膜由来線維芽細胞は EP 1 と EP 2 を発現していること, $\mathrm{PGE}_{2}$ による VEGF 産生はPKA 阻害薬により抑制され るが, PKCの down-regulation によっては影響されな いことから，EP 2-cAMP 系が関与していることを示唆 した。

動物レベルでも $\mathrm{PGE}_{2}$ による VEGF 産生に $\mathrm{cAMP}$ が 関与していることが示されている。Amanoら ${ }^{18)}$ は, ラットスポンジ移植モデルにおいて, $\mathrm{PGE}_{2}, \mathrm{cAMP} の$ アナログである 8-bromo-cAMP，adenylate cyclase の 
活性化薬 forskolin，あるいはcAMP 分解䣼素 phosphodiesterase の阻害薬 amrinone が VEGF の産生を光進す るとともに，血管新生を増大させることを示している。 これらの薬物によるVEGF の産生及び血管新生の元進 はPKA 阻害薬で抑制されることも示されており，in vivoに拈いても $\mathrm{PGE}_{2}$ は cAMP-PKAを介してVEGF の産生を誘導すると考えられる。これらの知見はまた $\mathrm{PGE}_{2}$ は $\mathrm{cAMP}$ の増加を誘導する $\mathrm{EP} 2 / \mathrm{EP} 4$ を介して VEGF を産生することを示唆している。一方，癌に伴う 血管新生について各種 $\mathrm{EP}$ 受容体欠損マウスを用いた解 析から，血管新生が EP 3 欠損マウスで著しく減弱する ことから EP 3 受容体を介するものであることが報告さ れた ${ }^{19)}$ 。EP 3 受容体には EP 2/EP 4 と同様に adenylate cyclase を活性化するサブクラスがあり，VEGF 産生に 関わる EP 受容体についてはさらに詳細な解析が必要で ある。また，PGE により活性化される $\mathrm{CAMP}-\mathrm{PKA}$ 経 路がどのようにVEGF の転写を促進するかについては 明らかではなく, HIF-1の転写活性に対する PKA の関 与の有無など，今後解明すべき点が残されている。

\section{VEGF 産生以外の作用}

$\mathrm{PGE}_{2}$ だけでなく, arachidonic acidの COX 代謝物の うち $\mathrm{TXA}_{2}$ 及び $\mathrm{PGI}_{2}$ にも血管新生促進作用があること が報告されている ${ }^{20)}$ 。これらの $\mathrm{PG}_{\mathrm{s}}$ は血管内皮細胞に直 接作用し，その遊走を誘導して血管新生を増大させる作 用を持つ。例えば TXA 2 の受容体拮抗薬は角膜に扔ける 血管新生モデルで，bFGFによる血管内皮細胞の遊走と 血管新生を抑制すること，また TX $\mathrm{A}_{2}$ アゴニストは COX-2 を阻害した条件下でこれらの反応を増大させる こと ${ }^{21)}$ が報告されている。また，IL- $1 \beta$ はヒト臍帯静脈 内皮細胞にCOX-2 の発現を誘導するとともにこの内皮 細胞の遊走を増大させること，この IL- $1 \beta$ による血管内 皮細胞の遊走は COX-2 阻害薬や EP 4 アンタゴニストあ るいは $\mathrm{TXA}_{2}$ アンタゴニストで抑制されること视が示さ れている。このように COX-2 は $\mathrm{PGE}_{2}$ だけでなく $\mathrm{TXA}_{2}$ の産生を介しても血管新生を増大させる。このほ か, $\mathrm{PG}_{\mathrm{s}}$ は血管内皮細胞の生存延長作用, matrix metalloprotease の誘導作用，IL-12 産生抑制作用などにより 血管新生を促進すること和が示唆されている。このよう に $\mathrm{PG}_{\mathrm{s}}$ にはVEGF の産生を六進するだけでなく,多様 な作用機構により血管新生を増加させる作用がある。

\section{9 おわりに}

血管新生は，癌細胞の増殖や転移などに関与している だけでなく，多くの炎症性疾患の病態形成にも梁く関 わっている。本総説に記載したように，筆者らを始め，
多くの研究グループが, 炎症局所で誘導された COX -2 により合成される $\mathrm{PGE}_{2}$ が VEGF の産生を介して肉芽組 織中の血管新生に関与することを明らかにした。また， COX-2 選択的阻害薬が, 抗炎症作用とともに血管新生 を抑制する作用をもつことも明らかになった。さらに， histamine ${ }^{22,23)}$ や bradykinin ${ }^{24)}$ など様々な炎症の mediators が血管新生に関与していることも明らかにされ，今 後, COX-2 選択的阻害薬を中心に薬物による血管新生 の制御の試みが急速に発展すると考えられる。

\section{文献}

1) J.R. Jackson, M.P. Seed, C.H. Kircher, D.A. Willoughby \& J.D. Winkler, FASEB J., 11, 457-65 (1997).

2) M. Ziche, J. Jones \& P.M. Gullino, J. Natl. Cancer Inst., 69, 475-82 (1982).

3) D.M. Form \& R. Auerbach, Proc. Soc. Exp. Biol. Med., 172, 214-8 (1983).

4) J. Frucht \& H. Zauberman, Br. J. Ophthalmol., 68, 656-9 (1984).

5) K.A. Houck, N. Ferrara, J. Winer, G. Cachianes, B. Li \& D.W. Leung, Mol. Endocrinol., 5, 1806-14 (1991).

6) A.K. Ghosh, N. Hirasawa \& K. Ohuchi, J. Pharm. Exp. Ther., 295, 802-9 (2000).

7) M. Murakami \& I. Kudo, Prog. Lipid Res., 43, 3-35 (2004).

8) S. Narumiya, Ann. New York Acad. Sci., 744, 126-38 (1994).

9) M. Majima, M. Isono, Y. Ikeda, I. Hayashi, K. Hatanaka, Y. Harada, O. Katsumata, S. Yamashina, M. Katori \& S. Yamamoto, Jpn. J. Pharmacol., 75, 105-14 (1997).

10) T. Kuwano, S. Nakao, H. Yamamoto, M. Tsuneyoshi, T. Yamamoto, M. Kuwano \& M. Ono, FASEB J., 18, 300-10 (2004).

11) D. Kamei, K. Yamakawa, Y. Takegoshi, M. MikamiNakanishi, Y. Nakatani, S. Oh-ishi, H. Yasui, Y. Azuma, N. Hirasawa, K. Ohuchi, H. Kawaguchi, Y. Ishikawa, T. Ishii, S. Uematsu, S. Akira, M. Murakami \& I. Kudo, J. Biol. Chem., 279, 33684-95 (2004).

12) E. Tischer, R. Mitchell, T. Hartman, M. Silva, D. Gospodarowicz, J.C. Fiddes \& J.A. Abraham, J. Biol. Chem., 266, 11947-54 (1991)

13) J.A. Forsythe, B.H. Jiang, N.V. Iyer, F. Agani, S.W. Leung, R.D. Koos, \& G.L. Semenza, Mol. Cell. Biol., 16, 4604-13 (1996).

14) G.L. Wang \& G.L. Semenza, J. Biol. Chem., 270, 1230-7 (1995).

15) S. Salceda \& J. Caro, J. Biol. Chem., 272, 22642-7 (1997).

16) S. Harada, J.A. Nagy, K.A. Sullivan, K.A. Thomas, N. Endo, G.A. Rodan \& S.B. Rodan, J. Clin. Invest., 93, 2490-6 (1994).

17) P. Ben-Av, L.J. Crofford, R.L. Wilder \& T. Hla, FEBS Lett., 372, 83-7 (1995).

18) H. Amano, K. Ando, S. Minamida, I. Hayashi, M. Ogino, S. Yamashina, H. Yoshimura \& M. Majima, Jpn. J. 
Pharmacol., 87, 181-8 (2001).

19) H. Amano, I. Hayashi, H. Endo, H. Kitasato, S. Yamashina, T. Maruyama, M. Kobayashi, K. Satoh, M. Narita, Y. Sugimoto, T. Murata, H. Yoshimura, S. Narumiya \& M. Majima, J. Exp. Med., 197, 221-32 (2003).

20) S. Gately, Cancer Metastasis Rev., 19, 19-27 (2000).

21) T.O. Daniel, H. Liu, J.D. Morrow, B.C. Crews, L.J. Marnett, Cancer Res., 59, 4574-7 (1999).
22) A.K. Ghosh, N. Hirasawa \& K. Ohuchi, Br. J. Pharmacol., 134, 1419-28 (2001).

23) A.K. Ghosh, N. Hirasawa, H. Ohtsu, T. Watanabe \& K. Ohuchi, J.Exp. Med., 195, 973-82 (2002).

24) Y. Ikeda, I. Hayashi, E. Kamoshita, A. Yamazaki, H. Endo, K. Ishihara, S. Yamashina, Y. Tsutsumi, H. Matsubara \& M. Majima, Cancer Res., 64, 5178-85 (2004). 